\title{
Risk perceptions in Japanese SMEs: the role of internet marketing capabilities in firm performance
}

Shane W. Mathews ${ }^{\mathrm{a} *}$, Masahiro Maruyama ${ }^{\mathrm{b}}$, Yuka Sakurai ${ }^{\mathrm{c}}$, Keith J. Perks ${ }^{\mathrm{d}}$ and Phyra Sok

${ }^{a}$ School of Business, Queensland University of Technology, Brisbane, Australia; ${ }^{b}$ Meiji Gakuin University, Tokyo, Japan; ${ }^{c}$ Faculty of Business Administration, St. Andrew's University, Osaka, Japan; ${ }^{d}$ Business School, University of Brighton, Brighton, England; ${ }^{e}$ and Department of Marketing, Monash University, Australia;

*Corresponding author: Dr Shane W. Mathews, Queensland University of Technology, School of Business, International Marketing, GPO Box 2434 Brisbane Qld 4001, Australia, +61 73138 5310, e-mail: sw.mathews@qut.edu.au

This is an Accepted Manuscript of an article published by Taylor \& Francis Group in Journal of Strategic Marketing17/04/2014, available online:

https://www.tandfonline.com/10.1080/0965254X.2018.1464048 


\section{Risk perceptions in Japanese SMEs: the role of internet marketing capabilities in firm performance}

Internet plays a very important role for the success of small and medium-sized enterprises (SMEs). Many Japanese SMEs are risk-averse in adopting technological innovation such as the Internet. Others, despite these risk-related business norms, recognize the importance of technology and develop and deploy Internet marketing technology to compete in the current competitive environment. Drawing upon these contradicting practices among Japanese SMEs, this study investigates how Japanese SMEs risk perception impacts on the deployment of Internet marketing capabilities, the relationships between perception of risk, international mindset, business networks, Internet marketing capabilities and firm performance. This study makes two contributions. Firstly, there has been limited research investigating how Internetrelated capabilities impact on firms' performance. Secondly, there are few Internet related studies in Japan. Thus, our emphasis on key antecedents and outcomes of Internet marketing capabilities among Japanese SMEs contributes significantly to our understanding of this unique contextual setting. The findings also provide some insights to managers/owners of Japanese SMEs that lower risk perception fosters adoption of the Internet and combined with other resources creates Internet marketing capabilities which results in higher performance.

Key words: Internet marketing capabilities; risk perception; international mindset

\section{Introduction}

Expansion holds greater risks and barriers for small, resource-poor firms in comparison to large, established multinationals as they lack the resources and have a narrower set of capabilities and less market knowledge (Lu \& Beamish, 2001; Musteen, Francis, \& Datta, 2010). In order to cope with these barriers and risks small and medium-sized enterprises (SMEs) rely on business relationships to access information and other resources (Jarillo, 1988) from network relationships to pursue opportunities (Coviello, 2006; Zahra, 2005). Furthermore, technological developments such as the Internet can be viewed as capabilities which can facilitate networks of information sharing, increase knowledge about markets and reduce the associated risks of new market entry (Mathews, Bianchi, Perks, Healy \& Wickramasekera, 2016).

Prior research argues that a country-specific context may have an impact on the adoption of these Internet technologies. Further, firm as well as country-contextual factors 
related to Internet adoption can be impediments to adoption (Tan, Tyler and Manica, 2007) in countries such as Japan. While in some areas there are high levels of Japanese technology acceptance, such as consumer technology acceptance (Barnes \& Huff, 2003), Japanese SMEs technology acceptance and implementation in general is low (Economist, 2010).

Even though Japan has a large and growing e-commerce market (Gibbs, Kraemer, \& Dedrick, 2003) there has been limited analysis of Internet use in SMEs. Additionally, the growth of Internet technology implementation is limited by a lack of skills in Japanese firms (Lohtia, Xie, \& Subramaniam, 2004; Fitzpatrick, 2015). This has been attributed to the riskaverse and uncertainty-avoidance mindset of owner managers (Yee, 2013). Further, Japanese SMEs have been reluctant to move beyond their domestic market and decoupled from the global economy Ibata-Arens, 2012) referred to as the Galapagos Syndrome effect (Economist, 2010).

Given the risk averse mind-set of Japanese owner managers and the reluctance to adopt Internet technology to exploit international markets this study aims to investigate how Internet marketing capabilities improves the performance of Japanese SME. The findings of this study not only contribute significantly to our understanding of this unique contextual setting, but also offer insights to owner managers of Japanese SMEs how to overcome the risk averse mind-set through the adoption of Internet technology such as Internet marketing capabilities.

\section{Development of the hypotheses}

A deficiency in market information availability increases the perceived risk, diminishing the firm’s strategic orientation towards international opportunities (Cavusgil, 1980; Melin, 1992). Online activities play a critical role in retrieving information and learning about markets (Nguyen \& Barrett, 2006; Yamin \& Sinkovics, 2006). Through the Internet firms can find 
information about the environment, competitors, customers and potential inter-firm collaborations (Nicovich \& Cornwell, 1988; Sharma \& Sheth, 200; Bennett, 1997; Weible \& Wallace, 1998). Further, the storage and digitalisation of information on the Internet increases the firm's access to international business and market information (Palmer \& Griffith, 1998), thus increasing information availability (Berry \& Brock, 2004; Brock \& Zhou, 2005; Hamill \& Gregory, 1997). For example the Internet accesses databases from government agencies, universities and research centres (Cronin McKim, 1996), thus reducing the perceived risk associated with market growth strategies (Mathews \& Healy, 2007). The Internet complements organizational and firm-level strategic resources and capabilities to improve competitive advantage and performance (Melville, Kraemer, \& Gurbaxani, 2004). The resource-based view posits that a firm's resources can be exploited to establish a distinct or rare advantage among the firm's competitors, which can be costly to imitate and without close strategic substitutes (Barney, 1991).

The perception of risk plays a key role in the development of new capabilities for superior performance. Those firms looking externally to grow, for example, are predisposed to developing new ways to operate innovatively. Further, firms pursuing an exploration strategy are more inclined to assume risk searching for new rather than existing market opportunities (Levinthal \& March, 1993). Therefore, to achieve new market growth these firms transform existing resources into new functional competencies to match and address new environmental conditions (Eisenhardt \& Martin, 2000). Therefore, we propose that: H1 Lower perceived risk leads to greater firm performance.

$\mathrm{H} 2$ Lower perception of risk has a positive impact on the international mindset of the firm.

Business network relationships enable a firm to accrue resources 'from the inter-firm networks in which they are located' (Gulati, 1999, p. 398), and social exchanges through interpersonal contacts between individuals may impact firm performance (Evangelista, 1996). 
Networks are based on exchange relationships, which evolve via mutual knowledge, trust, cooperation and social interaction, and can lead to improved market action and growth (Turnbull \& Valla, 1986; Young, Dimitratos, \& Dana, 2003; Wu, Mahajin, \& Balasubramanian, 2003). Resource-poor small firms participate in business networks to reduce the greater risks associated with new market expansion (Knight \& Liesch, 2002; Musteen et al., 2010).

In Japan there is a strong, embedded, interfirm, complex network culture, referred to as Keiretsu, a group or network that infuses market exchange with rich social relations of a noneconomic nature (Lincoln, Gerlach, \& Ahmadjian, 1996). Further there is a cultural predilection to use Keiretsu networks for group harmony and cohesiveness, with firms valuing long-term relationships with suppliers, distributors and customers (Kagono, Nonaka, Sakakibara, \& Okumura, 1985). Building relational capabilities to maintain customer and business network relationships (Jayachandran, Sharma, Kaufman, \& Raman, 2005) leads to market growth and performance (Morgan-Thomas, 2009; Musteen et al., 2010). Therefore, we propose that:

H3 Firm perceptions of risk have a positive influence on the usage of business networks.

H4 Business network usage leads to better firm performance.

Managers with an international mindset looking beyond current domestic markets, value diversity, seek openness, and empathetic to others are capable of establishing and developing non domestic business network relationships (Rhinesmith, 1995) and driving performance (Holm, Eriksson, \& Johanson, 1996). When top managers' attention is focused on strategic growth they are more likely to develop and maintain effective business network relationships with diverse stakeholders, including host governments, strategic partners, customers and suppliers (Rosenzweig \& Singh, 1991; Filatotchev, Liu, Buck, \& Wright, 2009). 
New technology platforms, such as the Internet, expose managers and organisations to individuals in other countries encouraging a willingness to learn about international markets. Such exposure to other individual fosters an ability to adapt to other cultures, a central characteristic of an international mindset (see for example Bartlett \& Ghoshal, 1989; Estienne, 1997). Further a firm’s Internet intensity influences decision-makers and the number of markets firms operate in (Moen, 2002). Further, there is a positive relationship between Internet intensity and the international mindset of the firm, which in turn influences the firm's vision, international strategy and performance (Aspelund and Moen (2004). Hence, we propose that:

H5 An international mindset of the firm leads to the development of business networks. H6 When a firm's managers have an international mindset the more business networks they will develop, leading to better firm performance.

The Internet facilitates efficient communication and the development of internal and external relations, increasing the frequency of generating opportunities (Mathews \& Healy, 2008; White \& Daniel, 2004). Further, Internet technology can be applied to a specific set of business capabilities, such as advertising and marketing, online sales, after sales service and market research, managing markets and operational data exchange (Aspelund \& Moen, 2004; Gibbs \& Kraemer, 2004).

The Internet improves communication and trust among parties, and the quality of business-related networks (Sigala, 2007; White \& Daniel, 2004). Business networks are a valuable resource for Internet-enabled SMEs, supporting their growth efforts (Loane \& Bell, 2006). The Internet contributes to the development of business networks, which in turn identifies and activates the exploitation of new market opportunities and growth (Petersen, Welch, \& Liesch, 2002). The connectivity and the interactivity of the Internet improves communication, commitment, satisfaction and trust among the parties, enhancing the quality 
of business network relationships (Bauer, Grether, \& Leach, 2002; Sigala, 2007). Thus, the Internet is important for maintaining business network relationships and establishing and maintaining networks. Based on these key findings, we propose that:

H7 Greater use of Internet marketing capabilities leads to greater use of business networks.

H8 Greater use of Internet marketing capabilities leads to greater firm performance.

$<$ Insert Figure 1 about here $>$

\section{Data and methodology}

We tested the hypotheses of perception of risk, international mindset, business networks and Internet marketing capabilities in Japanese SMEs. To emphasise the practical and theoretical relevance we pre-tested the survey instrument. Through the use of interviews with academics and practitioners we refined the measures and developed a questionnaire understandable for managers in Japanese SMEs.

Data for this research were collected using a postal survey method, with addresses extracted from Japanese Government's SME databases. At this point, the study informants were identified and chosen because of their particular knowledge of decisions related to Internet usage and their firm’s Internet marketing capabilities. Decision-makers knowledgeable about their firm’s business and Internet operations were asked to be key informants (Huber \& Power, 1985). Each invitation explained that the specific focus of the study was concerned with the Internet and the firm's business operations and only those responsible for these activities were invited to participate. Participants were also asked about their position in the firm and business activities, to ensure we obtained relevant and appropriate data to meet the aims of the study. The questionnaire was developed in English, then translated into Japanese by a member of the research team, and was then back-translated 
by other colleagues in the research team (as recommended by Brislin, 1970). There were 2753 surveys posted, with 356 returned, giving the study a response rate of 13\%. Six cases were deemed to have insufficient data and were therefore excluded as outliers. This left the study with 350 usable data responses. A total of 26\% of respondents were CEOs, $21 \%$ were directors and 53\% were managers and senior staff. Respondents had an average age of 49, an average of 20 years' experience in the industry and 17 years in their firm. On average firms had been established for 55 years and employed 148 employees, with an annual turnover of US\$2.5 million. The data was drawn from industrial goods manufacturing firms (25\%), consumer goods manufacturing firms (32\%) and wholesale/retail firms (43\%). The sample contained firms from across Japan, with 12\% of responses from Northern Japan, 23\% from Central Japan, 26\% from Eastern Japan, 27\% from Western Japan and 12\% from Southern Japan.

We followed the non-response bias examination method set out by Armstrong and Overton (1977), where we compared several key variables from early and late respondents in our sample. We used a time frame of two weeks to indicate a 'late respondent' (135) and, before that, early respondents (215). The t-tests showed no significant differences for any of the variables between the early and late respondent groups. We also examined the potential response bias that could possibly come from differences in firm size and industrial sector. The analysis showed no significant association between industry differences or firm size effects that would bias the study findings.

\section{Measurement}

\section{Perceived risk}

The perceived risk construct examines the firm’s view of their environment from a risk standpoint (Song \& Thieme, 2006); for example, 'How true are these statements? Customer 
demand for new products is highly predictable', with $1=$ strongly disagree and 7 = strongly agree, as seen in Table 1. Perceived risk had appropriate levels of construct validity with a factor loading of above .7, $\alpha$ at .89 and $\mathrm{KMO}$ at .743.

\section{International mindset}

The measure used to assess firms’ international mindset was derived from Nummela, Saarenketo and Puumalainen's (2004) view that international growth is a core objective of the firm and shows the firm having an international mindset. This construct has been shown to be effective in other SME Internet-focused studies (Aspelund \& Moen, 2004; Moen, 2002). For example, 'the firm emphasises the importance of growth, particularly international growth, to employees', with 1 = strongly disagree and 7 = strongly agree. International mindset had appropriate levels of construct validity with a factor loading of above $.6, \alpha$ at .90 and $\mathrm{KMO}$ at .883 .

\section{Business networks}

The business network measures were derived and adapted from Wu et al. (2003), where the extent of the use of business networks is assessed; for example, 'We use business networks for maintaining customer relationships', with $1=$ no usage and $7=$ extensive usage. Business networks had appropriate levels of construct validity with a factor loading of above $.6, \alpha$ at .91 and $\mathrm{KMO}$ at .821.

\section{Internet marketing capabilities}

We take our measure of Internet-related capabilities from previous work from Aspelund and Moen (2004), Gibbs and Kraemer (2004) and Glavas and Mathews (2014). These measures have been used to examine firm-level capability leveraging related to the Internet (see Glavas \& Mathews, 2014). For example, 'How much does the firm use the Internet for market 
research', with $1=$ no use and $7=$ extensive use. Internet marketing capabilities had appropriate levels of construct validity with a factor loading of above $.5, \alpha$ at .69 and KMO at 687.

\section{Firm performance}

Firm-level performance for SMEs was measured through a well-established set of items derived from Murphy, Trailer and Hill (1996), Wiklund (1999), and Butler, Keh and Chamornmarn (2000). For example, 'Relative to our competitors we have been successful related to profitability', with $1=$ strongly disagree and $7=$ agree strongly. Firm performance had appropriate levels of construct validity with a factor loading of above .7, $\alpha$ at .84 and KMO at .764.

To assess the likelihood of common method variance (CMV) we followed the approach set out by Podsakoff and Organ (1986) as the study has a single informant source and there is the possibility of bias or an over-inflated perception of the performances in relation to business activity. To counter this potential issue we asked all respondents to clarify performance indicators with those more knowledgeable about the financial aspects of the firm or to re-confirm with other senior staff. Because these were SMEs respondents may not have been able to confirm with other staff so we also asked for honesty in the responses, stressing the importance of accurate information. The study used a combination of anchor labels and questions to reduce the likelihood of common method bias.

Further, Podsakoff, Mackenzie, Lee and Podsakoff (2003) also suggest a Harman's one factor test in a confirmatory factor analysis (CFA), with the common latent factor showing an estimate of .05, which is very small with no major construct showing more than a .2 change as a consequence of evaluating the model with a common latent variable. Therefore, our evaluation indicates that no single factor accounts for the majority of the 
model and that CMV is not an issue. Finally, our model includes multiple interrelationships, therefore CMV bias is less likely, as respondents would find it difficult to form mental models of the relationships being investigated (Chang, Van Witteloostuijn, \& Eden, 2010; Podsakoff et al., 2003). These tests show no evidence of any CMV.

The overall measurement model employed 25 items to measure five main constructs and three control variables. Measurements included: constructs of perceived risk and international mindset, along with business network usage and Internet marketing capabilities, as well as a dependent variable of firm performance. Details of the individual items used to measure each construct are presented in Table 1.

\section{Results}

$<$ Insert Table 1 about here $>$

The hypotheses were tested using structural equation modelling. The model used in the analysis was estimated using IBM AMOS. The CFA shows reasonable fit for the proposed model, indicating there is a good statistical relationship between the factors: CMIN/DF= 3.48, $\chi 2=767.572$; d.f. $=220 ;$ RMSEA $=0.084 ;$ SRMR; .075; GFI=0.843, TLI = 0.879; CFI $=0.895$. However, the final model is a better model fit (with a few excluded items through parsimony, see Table 1) and is a better representation of the data, with model fit indices highlighting good model fit scores: $\mathrm{CMIN} / \mathrm{DF}=1.99, \chi 2=291.222$; d.f. $=146$; $\mathrm{RMSEA}=$ 0.053; SRMR= .052; GFI $=0.922, \mathrm{TLI}=0.960 ; \mathrm{CFI}=0.966$.

All of the regression coefficients in the structural equations are significant, except for H4 (business networks on firm performance) and H5 (international mindset on firm performance). The results support $\mathrm{H} 1$ and $\mathrm{H} 2$, which predict that a positive attitude toward risk in the business environment leads to increased firm performance $(\mathrm{H} 1 ; \beta=.32, \mathrm{p}<.001)$ and a positive view toward risk leads to an increased propensity to have an international mindset 
(H2; $\beta=.22, p<.001)$. Regarding H3, we found positive perceived risk to have a positive and significant effect on business networks $(\beta=.17, \mathrm{p}<.001)$. However, H4 and H5 were not supported; that is, a greater business network usage by the firm did not have a positive effect on firm-level performance $(\beta=.05, p=.168)$ and a greater international mindset of the firm did not necessarily lead to greater firm-level performance $(\beta=.10, p=.109)$, as illustrated in Figure 2.

$<$ Insert Figure 2 about here $>$

Conversely H6, H7 and H8 are supported. A greater international mindset has a positive impact on the usage of Internet marketing capabilities of the firm (H6; $\beta=.57$, $\mathrm{p}<.001)$. Internet marketing capabilities of the firm have a positive impact on the use of business networks $(\mathrm{H} 7 ; \beta=.42, \mathrm{p}<.001)$. Lastly, Internet marketing capabilities of the firm have a positive impact on firm-level performance $(H 8 ; \beta=.27, p<.001)$. The total standardized coefficients are presented in Table 2.

$<$ Insert Table 2 about here $>$

\section{Conclusion and discussion}

Positive and lower perceptions of risk are critical antecedent to the development of new types of capabilities such as Internet marketing. Our findings are that Japanese SMEs have lower perceptions of risk in the use of Internet marketing capabilities when expanding into new markets. This is similar to findings in the literature suggesting lower perceptions of risk encourage innovation giving an advantage to the firm (Song \& Thieme, 2006). 
However, positive perceptions of risk in and of itself do not lead to the development of Internet marketing capabilities. Our study found that an international mindset is needed combined with a positive perception of risk to fully deploy and exploit Internet marketing capabilities for firm-level performance. Moreover, the findings are that a combination or bundle of elements or capabilities, benefits firms in the exploitation of new types of Internetrelated marketing capabilities.

Further, the leveraging of Internet marketing capabilities led to greater overall firm performance. The development of these capabilities was dependent on having a combination of a positive view of risk as well as an externally focused growth-orientation or the presence of an international mindset in the firm.

The development of Internet business capabilities also had a positive impact on business network usage. However, contrary to the extant research evidence that business networks lead to firm-level financial performance (Turnbull \& Valla, 1986; Young et al., 2003; Wu et al., 2003) we did not find support for this. Our findings are similar to those of Lincoln et al. (1996), who found that the Keiretsu groups (highly networked firms) have a lower average profitability than independent firms. This may be due to the lack of capability development in highly networked firms in Japan where there are negative associations with group think (Tung, 2002) inhibiting SME exposure to new types of technological capabilities. However, business networks are valuable as they facilitate benefits such as knowledge transference (Davidsson \& Honig, 2003).

\section{Contributions and implications for practitioners}

This paper makes two contributions to knowledge and practice. Firstly, there has been limited research to measure and test how Internet-related capabilities impact on firms’ performance (Mathews et al., 2016). Our study contributes to this shortage of empirical testing of the 
connection between the development of Internet marketing capabilities and firm-level performance. This finding gives managers in Japanese SMEs confidence to develop and deploy technological capabilities as there is a beneficial performance outcome. However, the implication for Japanese SMEs is that in order to develop and deploy effective Internet marketing capabilities managers must create a culture whereby failure and risk-taking is part of the process of developing novel approaches towards marketing. Additionally to exploit Internet marketing capabilities Japanese SMEs should activate and foster the qualities needed for an international mindset. These qualities include a willingness to learn about international markets and an ability to adapt to other cultures.

Secondly, there are few Internet related studies in Japan with a focus on Internet marketing capabilities hence Japan is a unique contextual setting for our study. Our finding show that Japanese SMEs use Internet marketing capabilities to increase performance as well as develop business networks. However, these business networks do not have a direct impact on firm performance. Our findings highlight that Japanese SMEs accrue other benefits of Internet marketing capabilities namely increasing their innovative capacity and exploiting new international markets. The implications for Japanese SMEs are that they can focus managerial effort and time on new business networks as an alternative to a reliance on domestic Keiretsu groups for growth and access to new forms of innovation.

\section{Limitations and future directions for research}

Despite these contributions there are some limitations. Firstly, our study is cross-sectional of existing capabilities in the firm and does not evaluate the entire process through which firms develop capabilities. Rather the study evaluates the conditions needed to establish and leverage these capabilities. Therefore, the study gives little insight into the underlying processes used by Japanese SMEs to exploit resources in the development of new types of 
Internet capabilities. Further, the study focuses on Japanese SMEs and therefore the findings may not be transferrable to different country contexts. Other limitations are the effects of cultural dimensions, such as uncertainty avoidance affect management practices in relation to risk taking and Internet adoption (Valaei, et al. 2016).

However, the findings provide insights into countries where Internet resources and capability are lower than (for example the United States) and economies where business networks are entrenched (for example China). The insights from our study could therefore be tested and replicated in future research in contexts where technological development, use of Internet resources and business systems are similar to Japan. Further, because the study focuses on a specific country the constructs and items have been chosen to match the context. Hence, the study constructs and measures can be re-tested in similar market contexts to evaluate the measures and test the reliability of the model. As business networks were not found to have a direct impact on firm performance future studies could test our model on other benefits of business networks such as the development of knowledge capabilities. Finally, future studies could examine the effects of relevant cultural dimensions on Internet adoption and use as a capability in a multi-country cross cultural study.

\section{Acknowledgements}

We would like to thank the Service Innovation Research Program (SIRP) at Queensland University of Technology for their editorial and funding assistance.

\section{References}

Arenius, P., Sasi, V., \& Gabrielsson, M. (2005). Rapid internationalisation enabled by the Internet: The case of a knowledge intensive company. Journal of International Entrepreneurship, 3(4), 279-290.

Armstrong, J. S., \& Overton, T. S. (1977), Estimating nonresponse bias in mail surveys. Journal of Marketing Research, 14(3), 396-402. 
Aspelund, A., \& Moen, Ø. (2004), Internationalization of small high-tech firms: The role of information technology. Journal of Euro-Marketing, 13(2/3), 85-105.

Barnes, S., \& Huff, S., (2003), Rising sun: iMode and the wireless Internet. Communications of the ACM, 46(11).

Barney, J. B. (1991). Firm resources and sustained competitive advantage. Journal of Management, 17(1), 99-120.

Bartlett, C.A., \& Ghoshal, S. (1989). Managing across borders: The transnational solution. Boston: Harvard Business School Press.

Bauer, H. H., Grether, M., \& Leach, M. (2002). Building customer relations over the Internet. Industrial Marketing Management, 31, 155-163.

Bennett, R. (1997). Export marketing and the internet: Experiences of web site use and perceptions of export barriers among UK businesses. International Marketing Review, 14(5), 324-344.

Berry, M. M., \& Brock, J. K. U. (2004). Marketspace and the internationalisation process of the small firm. Journal of International Entrepreneurship, 2(3), 187-216.

Brislin, R. (1970). Back translation for cross-cultural research. Journal of Applied Psychology, 1, 185-216.

Brock, J. K. U., \& Zhou, Y. J. (2005). Organizational use of the Internet: Scale development and validation. Internet Research: Electronic Networking Applications and Policy, 15(1), 67-87.

Butler, J.E., Keh, H.T., \& Chamornmarn, W., (2000). Information acquisition, entrepreneurial performance and the evolution of modern Thai retailing. Journal of Asian Business, 16, 1-23.

Cavusgil, S. T. (1980). On the internationalization process of firms. European research, 8(6), 273-281.

Chang, S.-J., Van Witteloostuijn, A., \& Eden, L. (2010). From the editors: Common method variance in international business research. Journal of International Business Studies, $41,178-184$.

Coviello, N. E. (2006). The network dynamics of international new ventures. Journal of International Business Studies, 37(5), 713-731.

Cronin, B., \& McKim, G. (1996). Markets, competition, and intelligence on the World Wide Web. Competitive Intelligence Review, 7(1), 45-51.

Davidsson, P., \& Honig, B. L. (2003). The role of social and human capital among nascent entrepreneurs. Journal of Business Venturing, 18, 301-331. 
Eisenhardt, K., \& Martin, J. (2000). Dynamic capabilities: What are they? Strategic Management Journal, 21, 1105-1121.

Estienne, M. (1997). The art of cross-cultural management: An alternative approach to training and development. Journal of European Industrial Training, 21(1), 14-18.

Evangelista, F. (1996). Linking business relationships to marketing strategy and export performance: A proposed conceptual framework. Advances in International Marketing, 8, 59-83.

Filatotchev, I., Liu, X., Buck, T., \& Wright, M. (2009). The export orientation and export performance of high-technology SMEs in emerging markets: The effects of knowledge transfer by returnee entrepreneurs. Journal of International Business Studies, 40, 1005-1021.

Fitzpatrick, M. (2015, November 3). Why is hi-tech Japan using cassette tapes and faxes? $B B C$ News, Business reporter Tokyo.

Gibbs. J., Kraemer, K., \& Dedrick, J. (2003). Environment and policy factors shaping global - e-commerce diffusion: A cross-country comparison. The Information Society, 19(1), $5-18$.

Gibbs, J., \& Kraemer, K. (2004). A cross country investigation of the determinants of scope of e-commerce use: An institutional approach. Electronic Markets, 14(2), 124-137.

Glavas, C., \& Mathews, S. (2014). How international entrepreneurship characteristics influence Internet capabilities for the international business processes of the firm. International Business Review, 23(1), 228-245.

Gulati, R. (1999). Network location and learning: The influence of network resources and firm capabilities on alliance formation. Strategic Management Journal. DOI: 10.1002/(SICI)1097-0266(199905)20:5<397::AID-SMJ35>3.0.CO;2-K

Hamill, J., \& Gregory, K. (1997). Internet marketing in the internationalisation of UK SMEs. Journal of Marketing Management, 13(1-3), 9-28.

Holm, D. B., Eriksson, K., \& Johanson, J. (1996). Business networks and cooperation in international business relationships. Journal of International Business Studies, 27, 1033-1053.

Huber, G. P., \& Power, D. J. (1985). Retrospective reports of strategic level managers: Guidelines for increasing their accuracy. Strategic Management Journal, 6, 171-80.

Ibata-Arens, K. (2012, December 3). Solving the Japanese paradox. Asia Unbound, Council for Foreign Relations Blog.

Jarillo, J. C. (1988). On strategic networks. Strategic management journal, 9(1), 31-41. 
Jayachandran, S., Sharma, S., Kaufman, P., \& Raman, P. (2005). The role of relational information processes and technology use in customer relationship management. Journal of Marketing, 69(4), 177-192.

Kagono, T., Nonaka, I., Sakakibara, K., \& Okumura, A. (1985). Strategic vs. evolutionary management: A U.S.-Japan comparison of strategy and organization. Amsterdam: North-Holland.

Knight, G. A., \& Liesch, P. W. (2002). Information internalisation in internationalising the firm. Journal of Business Research, 55, 981-995.

Levinthal, D. A., \& March J. G. (1993). The myopia of learning. Strategic Management Journal, 14, 95-112.

Lincoln. J.R., Gerlach, M.L., \& Ahmadjian, C.L. (1996). Keiretsu networks and corporate performance in Japan. American Sociological Review, 61(1), 67-88.

Loane, S., \& Bell, J. (2006). Rapid internationalisation among entrepreneurial firms in Australia, Canada, Ireland and New Zealand. International Marketing Review, 23, 467-485.

Lohtia, R., Xie, T., \& Subramaniam, R. (2004). Efficient consumer response in Japan: Industry concerns, current status, benefits, and barriers to implementation. Journal of Business Research 57, 306- 311.

Lu, J. W., \& Beamish, P. W. (2001). The internationalization and performance of SMEs. Strategic management journal, 22(6-7), 565 -586.

Mathews, S., Bianchi, C., Perks, KJ., Healy, M., \& Wickramasekera, R. (2016). Internet marketing capabilities and international market growth. International Business Review, 25(4), 820-830.

Mathews, S., \& Healy, M. (2007). The Internet and information capability reduces perceived risk of internationalisation: An Australian SME perspective. International Journal of Organisational Behaviour, 12(1), 71-87.

Mathews, S., \& Healy, M. (2008). 'From garage to global': the internet and international market growth, an SME perspective. International Journal of Internet Marketing and Advertising, 4(2-3), 179-196.

Melin, L. (1992). Internationalization as a strategy process. Strategic management journal, 13(S2), 99-118. 
Melville, N., Kraemer, K., \& Gurbaxani, V. (2004). Review: Information technology and organizational performance: An integrative model of IT business value. MIS Quarterly, 28, 283-322.

Moen, Ø. (2002). The Internet and international marketing: An empirical analysis of small and medium sized Norwegian firms. Quarterly Journal of Electronic Commerce, 3(1), 31-41.

Morgan-Thomas, A. (2009). Online activities and export performance of the smaller firm: A capability perspective. European Journal of International Management, 3, 266-285.

Murphy, G.B., Trailer, J.W., \& Hill, R.C. (1996). Measuring performance in entrepreneurship research. Journal of Business Research, 36(1),15-23.

Musteen, M., Francis, J., \& Datta, D. (2010). The influence of international networks on internationalization speed and performance: A study of Czech SMEs. Journal of World Business, 45(3), 197-205.

Nguyen, T. D., \& Barrett, N. J. (2006). The adoption of the internet by export firms in transitional markets. Asia Pacific Journal of Marketing and Logistics, 18(1), 29-42.

Nicovich, S., \& Cornwell, T. B. (1998). An Internet culture?: Implications for marketing. Journal of Interactive marketing, 12(4), 22-33.

Nummela, N., Saarenketo, S., \& Puumalainen, K. (2004). A global mindset-a prerequisite for successful internationalization. Canadian Journal of Administrative Sciences, 21(1), 51-64.

Palmer, J. W., \& Griffith, D. A. (1998). Information intensity: a paradigm for understanding web site design. Journal of marketing theory and practice, 6(3), 38-42.

Petersen, B., Welch, L. S., \& Liesch, P. W. (2002). The Internet and foreign market expansion by firms. Management International Review, 42, 207-221.

Podsakoff, P. M., \& Organ, D. W. (1986). Self-reports in organizational research: Problems and prospects. Journal of Management, 12, 531-544.

Podsakoff, P. M., Mackenzie, S. B., Lee, J.-Y., \& Podsakoff, N. P. (2003). Common method biases in behavioral research: A critical review of the literature and recommended remedies. Journal of Applied Psychology, 88, 879-903.

Rhinesmith, S.H. (1995). Open the door to a global mindset. Training \& Development, 49(5), 35-43.

Rosenzweig, P. M., \& Singh, J. V. (1991). Organizational environments and the multinational enterprise. Academy of Management Review, 16, 340-361. 
Sharma, A., \& Sheth, J. N. (2004). Web-based marketing: The coming revolution in marketing thought and strategy. Journal of Business Research, 57(7), 696-702.

Sigala, M. (2007). Investigating the internet's impact on interfirm relations: Evidence from the business travel management distribution chain. Journal of Enterprise Information Management, 20, 335-355.

Song, M., \& Thieme, R. J. (2006). A cross-national investigation of the R\&D-marketing interface in the product innovation process. Industrial Marketing Management, 35, 308-322.

Tan. J., Tyler, K., \& Manica, A. (2007). Business-to-business adoption of e-Commerce in China. Information \& Management, 44, 332-351.

The Economist. (2010). SMEs in Japan, A new growth driver? The Economist Intelligence Unit.

Tung, R.L. (2002). Building Effective Networks. Journal of Management Inquiry, 11(2), 94101.

Turnbull, P., \& Valla, J. (1986). Strategies for international industrial marketing. London: Routledge.

Valaei, N., Rezaei, S., Ismail, W. K. W., \& Oh, Y. M. (2016). The effect of culture on attitude towards online advertising and online brands: applying Hofstede's cultural factors to internet marketing. International Journal of Internet Marketing and Advertising, 10(4), 270-301.

Yamin, M., \& Sinkovics, R. R. (2006). Online internationalisation, psychic distance reduction and the virtuality trap. International Business Review, 15(4), 339-360.

Yee, A. (2013). When Will Japan Tap Its Internet Potential?. Global Asia, 8(1), 80-85.

Young, S., Dimitratos, P., \& Dana, L.-P. (2003). International entrepreneurship research: What scope for international business theories? Journal of International Entrepreneurship, 1(1), 31-42.

White, A., \& Daniel, E. M. (2004). The impact of e-marketplaces on dyadic buyer-supplier relationships: Evidence from the healthcare sector. Journal of Enterprise Information Management, 17, 441-453.

Weible, R., \& Wallace, J. (1998). Cyber research: The impact of the Internet on data collection. Marketing Research, 10(3), 19.

Wiklund, J. (1999). The Sustainability of the Entrepreneurial Orientation--Performance Relationship. Entrepreneurship: Theory and Practice, 24(1), 37-37. 
Wiklund, J., \& Shepherd, D. (2003). Research notes and commentaries: Knowledge-based resources, entrepreneurial orientation, and the performance of small and mediumsized businesses. Strategic Management Journal, 24, 1307-1314.

Wu, F., Mahajin, V., \& Balasubramanian, S. (2003). An analysis of e-business adoption and its impact of business performance. Journal of the Academy of Marketing Science, 31, 425-447.

Zahra, S. A. (2005). Entrepreneurial risk taking in family firms. Family business review, 18(1), 23-40. 
Table 1. Measurement summary.

\begin{tabular}{|c|c|c|c|c|c|}
\hline Constructs & $\begin{array}{l}\text { Measure } \\
\text { Sources }\end{array}$ & Indicators & Mean & SD & $\begin{array}{l}\text { Factor } \\
\text { loading }\end{array}$ \\
\hline \multirow[t]{2}{*}{$\begin{array}{l}\text { Risk } \\
\text { perception }\end{array}$} & \multirow[t]{4}{*}{$\begin{array}{l}\text { Song \& Thieme } \\
\text { (2006) }\end{array}$} & \multicolumn{4}{|c|}{$\begin{array}{l}\text { The following questions are related to your firm. } 1 \text { = strongly disagree, } 7=\text { strongly } \\
\text { agree }\end{array}$} \\
\hline & & Customer demand for new products is highly predictable & 4.33 & 1.53 & .79 \\
\hline \multirow{9}{*}{$\begin{array}{l}\text { KMO }=.743 \\
\text { International } \\
\text { mindset } \\
(\mathrm{IM})(\alpha=.90) \\
\text { KMO }=.883\end{array}$} & & Occurrence of major technological change is highly predictable & 4.06 & 1.57 & .85 \\
\hline & & Competitors' product design changes are highly predictable & 4.18 & 1.54 & .82 \\
\hline & \multirow{7}{*}{$\begin{array}{l}\text { Aspelund \& Moen } \\
\text { (2004); } \\
\text { Moen (2002); } \\
\text { Nummela et al. } \\
\text { (2004) }\end{array}$} & \multicolumn{4}{|l|}{ The firm ... 1 = strongly disagree, 7 = strongly agree } \\
\hline & & ...is committed to servicing their international customers & 2.62 & 1.98 & .85 \\
\hline & & ...commits both financial and human resources & 2.17 & 1.65 & $.83 \#$ \\
\hline & & ...emphasizes importance of international growth to employees & 2.81 & 2.04 & .88 \\
\hline & & ...international experience is viewed as important & 3.79 & 2.20 & .67 \\
\hline & & ...regards the world as the market & 2.99 & 1.98 & .87 \\
\hline & & ...views fast international market growth as achievable & 2.99 & 1.90 & .83 \\
\hline Business & \multirow{5}{*}{ Wu et al. (2003) } & \multicolumn{4}{|c|}{ We use business networks to... 1 = no usage, and 7 = extensive usage } \\
\hline \multirow{4}{*}{$\begin{array}{l}\text { networks } \\
(\mathrm{BN}) \\
(\alpha=.91) \\
\text { KMO }=.821\end{array}$} & & ...maintain customer relationships & 4.24 & 1.94 & .94 \\
\hline & & ...strengthen existing relations & 4.05 & 1.99 & .96 \\
\hline & & ...develop longer-lasting relationships & 4.03 & 1.98 & .95 \\
\hline & & ....acquire new customers & 3.41 & 1.94 & $.69 \#$ \\
\hline $\begin{array}{l}\text { Internet } \\
\text { marketing }\end{array}$ & $\begin{array}{l}\text { Aspelund \& Moen } \\
\text { (2004); Gibbs \& }\end{array}$ & \multicolumn{4}{|c|}{$\begin{array}{l}\text { How much does your firm use the Internet for the following business processes or } \\
\text { activities? } 1=\text { no use and } 7=\text { extensive use }\end{array}$} \\
\hline capabilities & Kraemer (2004); & Online marketing and advertising & 2.86 & 1.82 & .51 \\
\hline (IBC) & Glavas \& Mathews & Online after sales service and support & 2.20 & 1.60 & .53 \\
\hline$(\alpha=.73)$ & $(2014)$ & Market research & 2.41 & 1.80 & .62 \\
\hline \multirow[t]{3}{*}{ KMO=.687 } & & Management of international market & 1.67 & 1.34 & .55 \\
\hline & & Exchange of operational data with suppliers & 2.80 & 2.04 & $.87 \#$ \\
\hline & & Exchange of operational data with business customers & 3.15 & 2.09 & $.87 \#$ \\
\hline \multirow{5}{*}{$\begin{array}{l}\text { Performance } \\
(\mathrm{FP}) \\
(\alpha=.84) \\
\text { KMO }=.764\end{array}$} & $\begin{array}{l}\text { Murphy, Trailer \& } \\
\text { Hill (1996); }\end{array}$ & \multicolumn{4}{|c|}{$\begin{array}{l}\text { The following questions are related to general firm performance, } 1=\text { strongly } \\
\text { disagree and } 7=\text { strongly agree }\end{array}$} \\
\hline & Wiklund \& Sheperd & Profitability & 3.84 & 1.60 & .82 \\
\hline & (2003); Butler, Keh & Sales growth & 3.65 & 1.59 & .83 \\
\hline & $\&$ & Market share & 3.74 & 1.56 & .77 \\
\hline & $\begin{array}{l}\text { Chamornmarn } \\
(2000)\end{array}$ & Overall performance & 4.10 & 1.42 & .90 \\
\hline
\end{tabular}

Note. $\alpha=$ Cronbach Alpha a standardized estimate; $R P=$ Risk perception; IM = International mindset; $B N=$ Business networks; IBC = Internet marketing capability; FP = Firm performance, $\#=$ Items that have been excluded in the final model. 
Table 2. Correlation coefficients.

\begin{tabular}{lllllllll}
\hline & 1 & 2 & 3 & 4 & 5 & 6 & 7 & 8 \\
\hline 1. Perceived risk & & & & & & & \\
2. International mindset & $0.27^{* * *}$ & & & & & & \\
3. Business networks & $0.26^{* * *}$ & 0.07 & & & & & \\
4. Internet marketing capabilities & 0.01 & $0.34^{* * *}$ & $0.87^{* * *}$ & & & & & \\
5. Firm-level performance & $0.33^{* * *}$ & 0.10 & 0.05 & $.038^{* * *}$ & & & \\
6. Firm size & 0.04 & $0.11^{*}$ & 0.07 & 0.00 & $0.15^{* *}$ & & \\
7. Industry & 0.08 & $-0.34^{* * *}$ & 0.05 & 0.05 & 0.02 & 0.08 & \\
8. Firm age & 0.02 & 0.03 & 0.07 & 0.05 & 0.00 & 0.04 & 0.07 \\
\hline
\end{tabular}

Note: ${ }^{* * *}=\mathrm{p}<.001,{ }^{* *}=\mathrm{p}<.01,{ }^{*}=\mathrm{p}<.05$. 


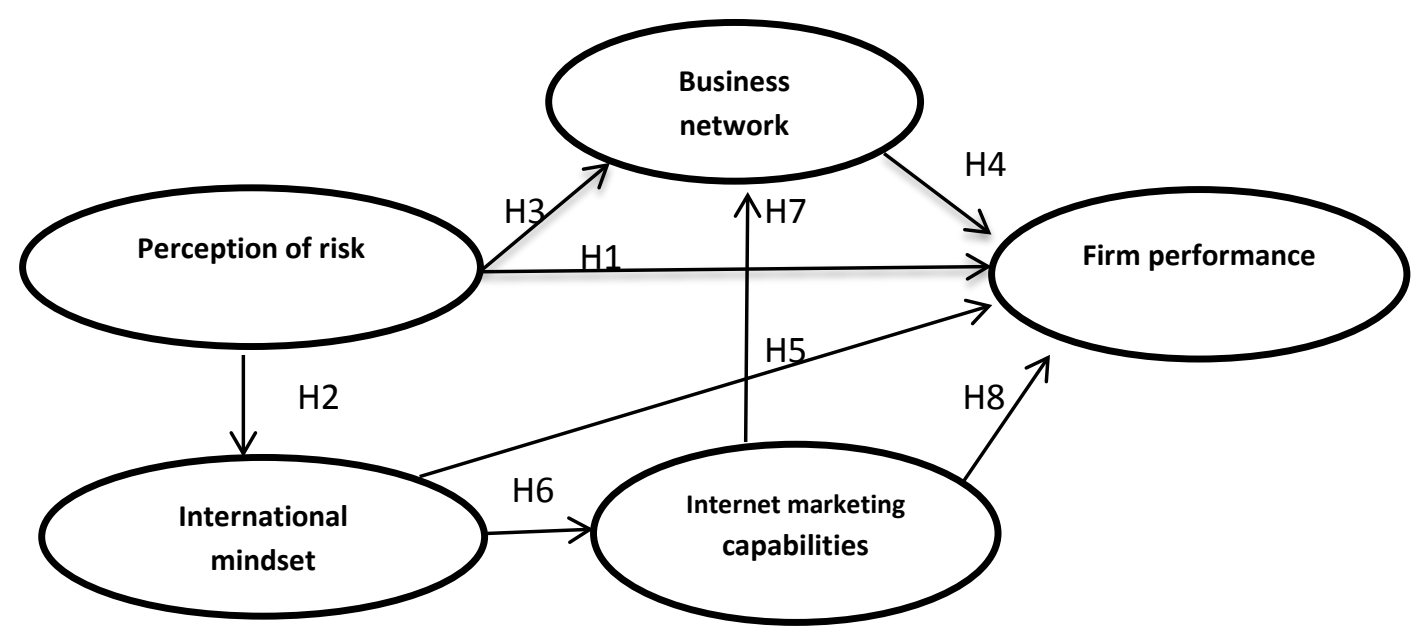

Figure 1. Proposed conceptual model (8 hypotheses). 


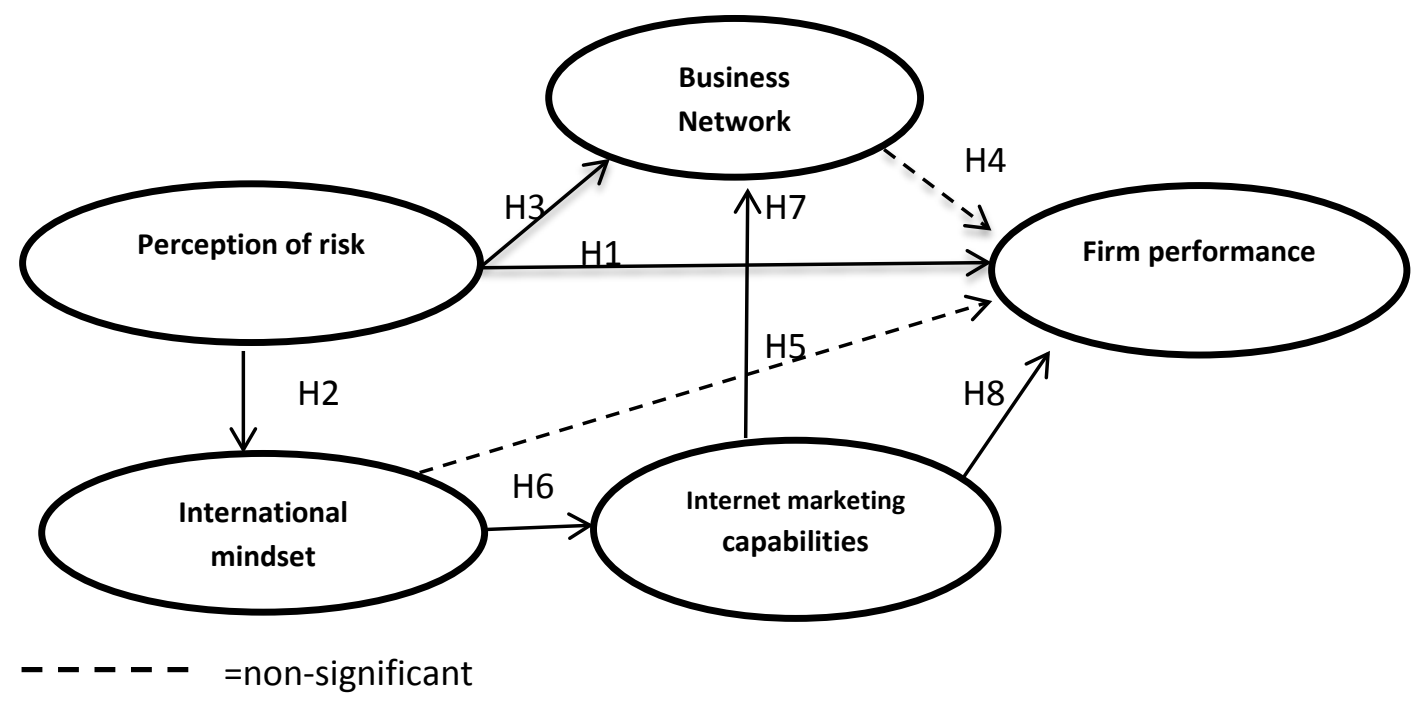

Figure 2. Final model (8 hypotheses). 